Journal of Education and Educational Development

7(1), 157-176, 2020.

DOI: http://dx.doi.org/10.22555/joeed.v7i1.1476

\title{
Student Optimism - Grading of an Experiential Learning Project
}

\author{
Nawaz Ahmad \\ Institute of Business Management, Pakistan \\ nawaz.ahmad@iobm.edu.pk \\ Sarwat Nauman \\ Institute of Business Management, Pakistan \\ sarwat.nauman@iobm.edu.pk
}

\begin{abstract}
In order to obtain good grades, students involve themselves in hard work according to the best of their ability, yet an experiential learning project makes it even harder to attain the grades that the students are aiming for. Researches have shown that students are generally optimistic about their grades, yet no research has been found in Pakistan to gauge student optimism in grades with regard to experiential learning projects. This study is an attempt to gauge an empirical attempt to gauge students' optimism towards their grades in an experiential learning project. A sample of 106 students is obtained via purposive sampling technique enrolled in the same university and same course. After being involved in an experiential learning project, they were asked their expected marks which were compared later with their actually obtained marks. Pair sample t-test is applied to figure out whether the average of perceived marks is statistically different than the average of actually obtained marks. The average of expected marks exceeds by 2.14 which is statistically significant at $99.9 \%$ confidence interval.
\end{abstract}

Keywords: business graduates, experiential learning, grade expectations, student expectations 


\section{Introduction}

\section{Background of the Study}

Experiential learning has now replaced the traditional method of learning where the students were passive and behavioural approach was used to instil particular behaviour in them. (Javed, Hussain, \& Karim, 2014; Jeyaraj, 2019; Kamath, 2014). Now, the learning is cognitive and social where the constructivist approach is followed and when students take part in active learning the idea of meaningful learning is reinforced (Chana, 2012). Experiential learning takes place when students involve themselves in real life experiences and use their classroom knowledge to enhance their understanding and learning (Chana, 2012). Thus, like elsewhere in the world, Pakistan is also trying to replace its didactic form of learning with experiential learning. The assessment and grading of these projects also differ from the usual grading system. Since an experiential project at a university level is usually of one to two weeks, therefore the grading is also longitudinal and continuous. Students thus at the beginning of a course have high hopes and believe to score good grades in it (Khachikiana, Guillaumea, \& Phama, 2011; Larseingue, Sawyer, \& Finn, 2012). This expectation of scoring a good grade increases in an experiential setting as the students think that since they neither cram nor practice, therefore they will attain high grades.

Khachikiana, Guillaumea and Phama (2011) conducted their research on engineering students where they were to self evaluate their work and grade themselves. It was found out that students started off with a realistic approach towards grade attainment and the students with high GPA continued to adjust their working hours and study approaches according to their expected grade. This showed that these students were well aware of the faculty expectation and their own capacity and ability. Whereas students with low GPA were overly optimistic about their grades and were unsure of their own capabilities and could not commit to the work that was required, adding to their disappointment by attaining low grades at the end of the course. Students and faculty both believe that the more time you spend on a task, the better grades will you be able to achieve, but the results show that there is no correlation between the hours spent on a task and the grades achieved by the student (Guillaumea \& Khachikianb, 2011). Therefore, the faculty should first identify individual weaknesses of students and then focus on these weaknesses so that the students learn to work 'smart' along with 'hard' (Guillaumea 
\& Khachikianb, 2011). Even though an experiential project is a time related and time-consuming activity, yet scoring a high grade on a project is based upon many things and does not always correlate with the time spent on the project at hand.

Similarly, Larseingue, Sawyer and Finn (2012) found out that in speech courses, which are experiential in nature, three components affected grade expectation of undergraduate students. Firstly, the course rigour - the perceived toughness of a course; secondly, teacher communication behaviour and thirdly, perceiver effect how one perceives one's own strengths and weaknesses. These three components of grade expectation can be generalized to almost all types of tests and evaluations. Nevertheless, it must be understood that in the case of an experiential learning project, the students feel that the grades will not be difficult to achieve as it seems to be easier than learning theories. Therefore, all three components that effect grade expectation are high for an experiential learning project, resulting in a high expectation of grade. But the matter of fact is that there are many dimensions to an experiential learning project and however easy it may seem to the students, they have to go through a rigorous grading system. With this in mind, the researchers have looked into the student optimism regarding their grades in an experiential learning project in an undergraduate course at a business university.

\section{Research Question}

To what extent do the business university students hold grade optimism in an experiential learning project?

\section{Hypotheses}

H1: There is no significant difference between the expected and actual marks obtained.

H2: There is no significant difference between expected and actual marks obtained by female respondents.

H3: There is no significant difference between expected and actual marks obtained by male respondents.

H4: There is no significant difference between expected and actual marks obtained by undergraduate respondents.

H5: There is no significant difference between expected and actual marks obtained by graduate respondents. 
H6: There is no significant difference between expected and actual marks obtained by female undergraduate respondents.

H7: There is no significant difference between expected and actual marks obtained by male undergraduate respondents.

H8: There is no significant difference between expected and actual marks obtained by female graduate respondents.

H9: There is no significant difference between expected and actual marks obtained by male graduate respondents.

\section{Literature Review}

Carpenter, Friar and Lipe (1994) concluded that minority students and female students had a lower expectation of grades than the majority and male students. When the expected grades and the achieved grades were compared, it was revealed that correlation was strong between the expected and actual grades of majority students as compared to those of minority students. On the other hand, the correlation between the expected and the obtained grades of males was stronger than those of females. The authors argued that the correlation of grades between the expected and the obtained grades of minority students and of female students is not strong because their expectations are influenced by their past experiences. Carpenter, Friar and Lipe have pointed out only one reason, but there may be other reasons as well; like the ones unearthed by Centra (2003).

According to Centra (2003), the students' expected grades for a course were lower if the course was either too difficult or too elementary. On the other hand, the courses that were considered to be of an appropriate level for students received higher grade expectation (Centra, 2003). Students also expect a higher grade from a course if they feel that they have learnt more in that course and have worked hard (Centra, 2003). Jama and Pitts (2005) add to this discussion by highlighting the role of a teacher. They hold that the students' grades are influenced by teachers' grade expectations of their students. They proved that the African American children expected and obtained lesser grades than their White counterparts as the teachers expected the White students to get higher grades than the African American students. Thus, students' self-evaluation is dependent upon the teacher's expectation. If a teacher expects low grade from a student, he/she will also expect a low grade and vice versa. 
Grade expectation also depends upon the way an instructor conducts a course: what expectations and benchmarks do he/she lay down for the students and what pedagogy he/she uses to deliver the knowledge. White (2007) concluded that the pedagogy effects the way students think of grade achievement. He compared two groups of students using different pedagogies for the same course. One group was taught using problem-based learning (PBL) and others through the traditional method. It was revealed that those who taught through PBL, embraced independence, responsibility for their work, achieved satisfactory grades and "expressed a high degree of satisfaction with their program and the faculty who taught them" ( $p$. 292). On the other hand, the students who learnt through the traditional method were dependent on their faculty and blamed the faculty for not attaining the grades that they were expecting from the course. The study concludes that pedagogy is a fundamental factor in grade expectation. The students favour experiential learning and consider this type of teaching pedagogy to be more effective than traditional classroom teaching (Phipps, Phipps, Kask, \& Higgins, 2001; White, 2007). Where experiential learning led to a more realistic view of one's own grades, this positivity towards the experiential learning pedagogy used in the deliverance of a course may lead to high-grade expectation.

Experiential learning is rated highly by university students because of the students at the level value self-efficacy and self-directed learning (Fenollar, Roman, \& Cuestas, 2007). It thus becomes important for students to perceive themselves as confident individuals who have self-assurance in their own capacities and capabilities and all their learning is self-directed (Fenollar, Roman, \& Cuestas, 2007). Nevertheless, Bell and Federman, (2010) proposed that students' selfassessment should be studied in an experiential setting due to two important reasons. The first reason according to them is that educational institutes are moving towards experiential learning where more importance is given to problem-based learning or project-based learning. Secondly, they explained the on-job training focus more on building skills of individuals that are specific to the learner's job. They emphasized the need to hold research in self-assessment in an experiential learning project as most of the research they argued on self-assessment is conducted in a classroom setting. They emphasized that the results of self-assessment may be different in a classroom setting as compared to the one conducted in an experiential setting.

On the other hand, Sitzmann, Ely, Brown and Bauer, (2010) gave two 
recommendations that would help students assess themselves more accurately. They stressed that feedback should be regularly provided to the students as it helps them to determine their academic standing and secondly if self-assessment is considered a skill then, their self-assessment skills should be fostered. It must also be kept in mind that students will feel more responsible for the grades that they have achieved if they are given more autonomy to take decisions (Pew, 2007). In higher education, the students should be given more autonomy and control over their learning and experiential learning can help faculty achieve this. It should be kept in mind that "when adults are treated like adults, they often behave like responsible adults; when treated like children, they often behave as such" (p.23). Hence, their grade expectations will be more realistic and they will accept the responsibility of the grades that they have achieved.

\section{Methodology}

\section{Data and Variables}

Quantitative study design was used to confirm or reject the given hypotheses. The questionnaire was self-constructed and consisted of two parts. Primary data were collected via a structured questionnaire containing demographics, such as gender, educational level in the first part and the expected marks as per participants' expectations in the second part. At the end of the experiential activity, the actual marks obtained by the participants were taken from the faculty in-charge.

\section{Sample and Sampling Technique}

The sample consisted of 106 respondents comprising male and female, who studied at the undergrad and graduate level in a business school. The sample was obtained via purposive sampling technique; therefore, it was selected from all those university students who were part of the experiential learning project. According to the research ethics, the students and the faculty in charge were briefed about the study and they had the liberty to leave the study if they did not want to be a part of the project.

\section{Inclusion Criteria}

All studnets who were working under the same mentor on the experiential project were included as sample for the research study, so that they had common features. 


\section{Statistical Technique}

The aim of this study is to gauge whether students' expectations regarding their grades matched the reality or not; therefore, paired sample t-test was applied to figure out whether the average score of students' expected grades is equal to the average score of actual grades where the expected grades were obtained before the assessment wherfrom the actual grades were obtained.

$$
t=\frac{\sum d}{\sqrt{\frac{n\left(\sum d^{2}\right)-\left(\sum d\right)^{\wedge} 2}{n-1}}}
$$

Where

$\mathrm{t}=$ pair sample $\mathrm{t}$-test

$\mathrm{d}=$ difference of expected and actual marks

$\mathrm{n}=$ sample size

\section{Findings}

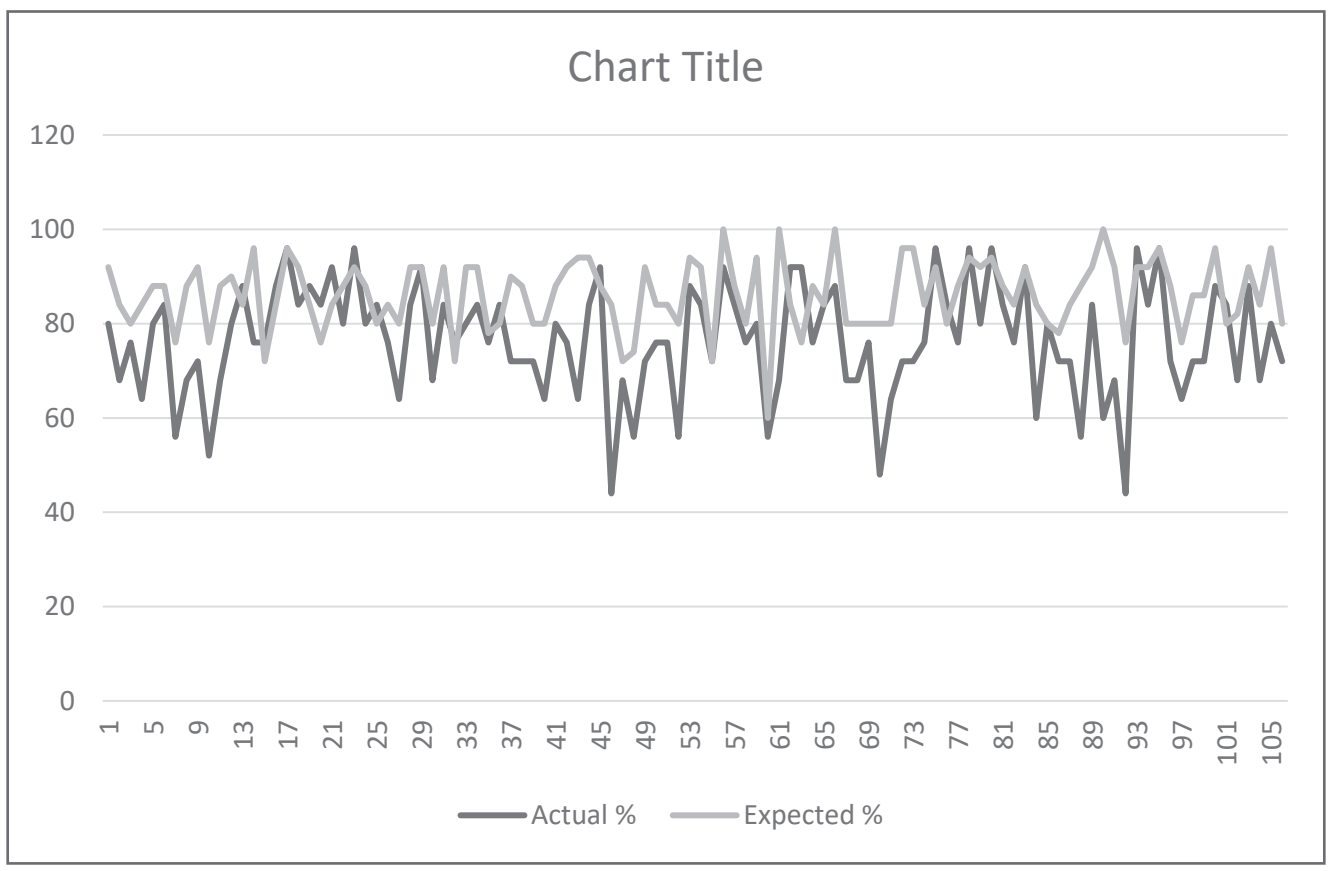

Figure 1. Actual marks of experiential learning students vs their corresponding expected marks 
The graph shows actual marks of experiential learning students vs their corresponding expected marks. It is evident from the graph that expected marks are at the higher end compared with corresponding actual marks which depict the students' behaviour of being optimistic regarding their performance. The graph further depicts that the students who expected higher are relatively at higher side and vice versa besides a certain number of students who are otherwise.

Table 1

Descriptive Analysis

\begin{tabular}{lcccccc}
\hline & \multicolumn{6}{c}{ Descriptive Statistics } \\
& N & Range & Minimum & Maximum & Mean & Std. Deviation \\
\hline Actual & 106 & 52.00 & 44.00 & 96.00 & 76.4906 & 11.77184 \\
Expected & 106 & 40.00 & 60.00 & 100.00 & 86.1509 & 7.39471 \\
Marks_Difference & 106 & 56.00 & -40.00 & 16.00 & -9.6604 & 10.79849 \\
Valid N (listwise) & 106 & & & & & \\
\hline
\end{tabular}

Let's talk about students' expectations first, a minimum score is of $60 \%$ i.e. every student is aiming at least a pass grade and maximum - sky is the limit, they are expecting cent per cent marks with the wider range of 52\% score whereas actual is relatively another way around with fail grades and maximum $96 \%$ score. Moreover, average scores of expected and actual are also differed by $9.66 \%$.

Marks difference is obtained by taking away expected marks from actual marks. It shows interesting findings that there is a $40 \%$ score difference is observed between the minimum of actual and expected score whereas at the maximum end this difference is reduced to $16 \%$. These statistics show that students who score high are more ascertain regarding their marks comparatively.

Table 2

Comparing overall scores (Paired Samples Statistics)

\begin{tabular}{llcccc}
\hline \multicolumn{5}{c}{ Paired Samples Statistics } \\
& & Mean & N & Std. Deviation & Std. Error Mean \\
\hline \multirow{2}{*}{ Pair 1 } & Actual & 76.4906 & 106 & 11.77184 & 1.14338 \\
& Expected & 86.1509 & 106 & 7.39471 & .71824 \\
\hline
\end{tabular}

Pair sample t-test is applied to compare actual and expected score obtained 
by the students who are the part of an experiential learning project. The average score of expected grades is $86.15 \%$ which is evidently higher than the average score of actual grades which is $76.49 \%$. The average difference of both the scores is observed as $9.66 \%$, with this magnitude expected score exceeds the actual. Moreover, smaller standard deviation (7.39\%) of expected score depicts lesser diversity while making expectations compared with $11.77 \%$ of the actual score which reflects that reality is worse if expectations are high.

Table 3

Comparing overall scores (Paired Samples Correlations)

\section{Paired Samples Correlations}

\begin{tabular}{lcccc} 
& & N & Correlation & Sig. \\
\hline Pair 1 & Actual \& Expected & 106 & .440 & .000 \\
\hline
\end{tabular}

The correlation between actual and expected scores depicts that if a student obtains high grade provided he has expected high grade and vice versa ie those who expected high, scored high grades and those who expected lower, got lower grades. Here, 44\% interdependence is observed, though it's significant yet it shows variations between actual and expected scores.

Table 4

Comparing overall scores (Paired Samples Test)

\section{Paired Samples Test}

Paired Differences

\begin{tabular}{ccccccccc} 
& Mean & $\begin{array}{c}\text { Std. } \\
\text { Deviation }\end{array}$ & \multicolumn{2}{c}{$\begin{array}{c}\text { Std. } \\
\text { Mean }\end{array}$} & $\begin{array}{c}\text { 95\% Confidence Interval } \\
\text { of the Difference } \\
\text { Lower }\end{array}$ & T & df & Sig. \\
(2-tailed)
\end{tabular}

The mean difference between expected and actual scores is observed as $9.66 \%$ where expected score exceeds the actual one. In order to gauge whether this difference is significant or not, paired sample t-test is applied which gives test statistics' value of 9.21 which is greater than 2 - the benchmark for t-test followed by sig value of 0.000 which is lesser than 0.01 , it is evident that students' expected score exceeds than the actual score and is significant at $1 \%$ (level of significance). 
Table 5

Comparing gender wise score (Paired Samples Statistics)

\begin{tabular}{lllcccc}
\hline & & \multicolumn{2}{c}{ Paired Samples Statistics } \\
& \multirow{2}{*}{ Gender } & Mean & N & Std. Deviation & Std. Error Mean \\
\hline \multirow{2}{*}{ Female } & \multirow{2}{*}{ Pair 1 } & Actual & 80.8571 & 28 & 12.28584 & 2.32181 \\
& & Expected & 86.7143 & 28 & 6.73772 & 1.27331 \\
\multirow{2}{*}{ Male } & \multirow{2}{*}{ Pair 1 } & Actual & 74.9231 & 78 & 11.25244 & 1.27409 \\
& & Expected & 85.9487 & 78 & 7.64793 & .86596 \\
\hline
\end{tabular}

In order to get more insights, the data has been split on gender basis and for each gender, actual and expected marks were analyzed. The statistics show that females are apparently more conscious while expecting whereas males don't care as the average scores of actual and expected for females are closer compared with males. Moreover, the standard deviation shows variations in marks. It is observed that the actual score has more variations for both the gender compared with expected score and females' actual score has even higher variations compared with males' actual score.

Table 6

Comparing gender wise score (Paired Samples Correlations)

\begin{tabular}{lccccc}
\hline & \multicolumn{2}{c}{ Paired Samples Correlations } & \\
& Gender & N & Correlation & Sig. \\
\hline Female & Pair 1 & Actual \& Expected & 28 & .175 & .373 \\
Male & Pair 1 & Actual \& Expected & 78 & .534 & .000 \\
\hline
\end{tabular}

Females' actual and expected scores have no correlation ie both the scores are well scattered compared with males. Male students' actual and expected marks are significantly associated ie those who expected higher, are at the higher end compared with those who expected lower marks.

Table 7

Comparing gender wise score (Paired Samples Test)

\begin{tabular}{|c|c|c|c|c|c|c|c|c|c|c|}
\hline \multirow{3}{*}{ Gender } & \multicolumn{10}{|c|}{ Paired Differences } \\
\hline & & & \multirow[t]{2}{*}{ Mean } & \multirow[t]{2}{*}{$\begin{array}{c}\text { Std. } \\
\text { Deviation }\end{array}$} & \multirow{2}{*}{$\begin{array}{l}\text { Std. } \\
\text { Error } \\
\text { Mean }\end{array}$} & \multicolumn{2}{|c|}{$\begin{array}{l}95 \% \text { Confidence } \\
\text { Interval of the } \\
\text { Difference }\end{array}$} & \multirow[t]{2}{*}{$\mathbf{T}$} & \multirow[t]{2}{*}{ df } & \multirow[t]{2}{*}{$\begin{array}{c}\text { Sig. } \\
\text { (2-tailed) }\end{array}$} \\
\hline & & & & & & Lower & Upper & & & \\
\hline Female & Pair 1 & Actual - Expected & -5.85714 & 12.9377 & 2.44501 & -10.87389 & -.84039 & -2.396 & 27 & .024 \\
\hline Male & Pair 1 & Actual - Expected & -11.0256 & 9.65237 & 1.09292 & -13.20191 & -8.84937 & -10.088 & 77 & .000 \\
\hline
\end{tabular}


In order to gauge whether actual and expected scores are statistically alike with reference to gender, a pair sample t-test is applied to gauge the mean score difference of actual and expected scores for male and female respondents. On average, female respondents expect $5.85 \%$ higher score than they actually obtained whereas male respondents expect $11.02 \%$ higher than they actually obtained. Both mean scores are significant as absolute t-value is greater than 2 - inch mark. Sig value reflects that mean score difference is significant at $5 \%$ for females as sig value $(0.025)$ is lesser than 0.05 and at $1 \%$ for males as sig value $(0.00)$ is lesser than $1 \%$.

Table 8

Comparing educational level wise score (Paired Samples Statistics)

\begin{tabular}{|c|c|c|c|c|c|c|}
\hline \multicolumn{3}{|c|}{ Education_Level } & Mean & $\mathbf{N}$ & Std. Deviation & Std. Error Mean \\
\hline \multirow{2}{*}{ Undergraduate } & \multirow{2}{*}{ Pair 1} & Actual & 76.5000 & 48 & 11.33250 & 1.63571 \\
\hline & & Expected & 85.4167 & 48 & 6.71560 & .96931 \\
\hline \multirow{2}{*}{ Graduate } & \multirow{2}{*}{ Pair 1} & Actual & 76.4828 & 58 & 12.22198 & 1.60483 \\
\hline & & Expected & 86.7586 & 58 & 7.91913 & 1.03983 \\
\hline
\end{tabular}

Education level does not matter, students always expect at higher side. For both, undergrad and graduate level, students' expectations regarding their scores are higher than they actually obtained. Moreover, higher variations are observed in their actual marks compared with their expected marks as standard deviations for actual marks are higher than expected marks.

Table 9

Comparing educational level wise score (Paired Samples Correlations)

\begin{tabular}{lllccc}
\hline Education_Level & & & N & Correlation & Sig. \\
\hline Undergraduate & Pair 1 & Actual \& Expected & 48 & .415 & .003 \\
Graduate & Pair 1 & Actual \& Expected & 58 & .460 & .000 \\
\hline
\end{tabular}

Both levels, graduate and undergrad, students' actual and expected marks have interdependence which is significant at $1 \%$. 
Table 10

Comparing educational level wise score (Paired Samples Test)

Paired Differences

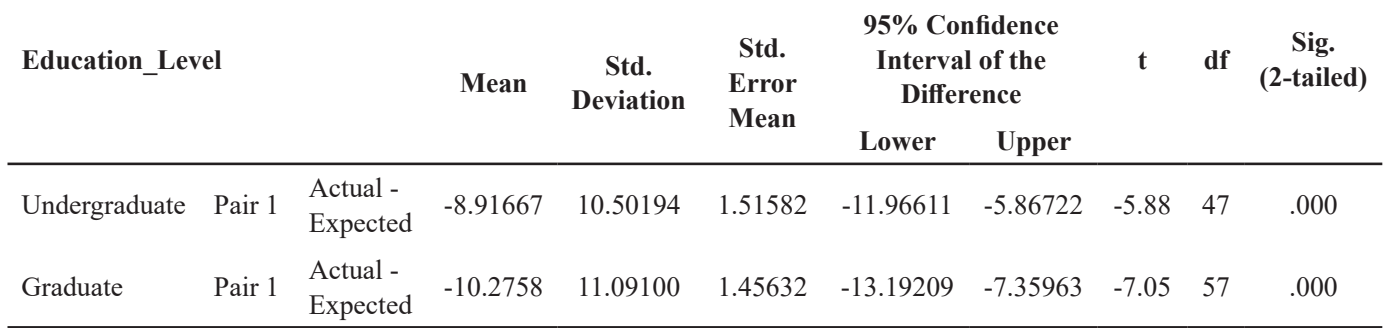

In order to investigate students' actual and expected marks difference with reference to education level ie undergrad and graduate level, once again paired sample-test is applied and the result shows that the difference is statistically significant at $1 \%$ for both the levels.

Table 11

Comparing gender wise score with education level (Paired Samples Statistics)

\begin{tabular}{|c|c|c|c|c|c|c|c|}
\hline Education_Level & Gender & & & Mean & $\mathbf{N}$ & Std. Deviation & Std. Error Mean \\
\hline \multirow{4}{*}{ Undergraduate } & \multirow{2}{*}{ Female } & \multirow{2}{*}{ Pair 1} & Actual & 80.0000 & 14 & 12.93772 & 3.45775 \\
\hline & & & Expected & 84.8571 & 14 & 4.81755 & 1.28754 \\
\hline & \multirow{2}{*}{ Male } & \multirow{2}{*}{ Pair 1} & Actual & 75.0588 & 34 & 10.47057 & 1.79569 \\
\hline & & & Expected & 85.6471 & 34 & 7.40959 & 1.27073 \\
\hline \multirow{4}{*}{ Graduate } & \multirow{2}{*}{ Female } & \multirow{2}{*}{ Pair 1} & Actual & 81.7143 & 14 & 12.02196 & 3.21300 \\
\hline & & & Expected & 88.5714 & 14 & 7.97799 & 2.13221 \\
\hline & \multirow{2}{*}{ Male } & \multirow{2}{*}{ Pair 1} & Actual & 74.8182 & 44 & 11.94030 & 1.80007 \\
\hline & & & Expected & 86.1818 & 44 & 7.90429 & 1.19162 \\
\hline
\end{tabular}

Females' actual and expected average scores for graduate as well as undergrad level are closer compared with male counterparts. Moreover, expected scores have lesser variations compared with actual as their standard deviations are smaller. Undergrad female students have the least variation across their expected score and highest across the actual score. At the undergrad level, male students expect better score whereas, at the graduate level, female students expect better. 
Table 12

Comparing gender wise score with education level (Paired Samples Correlations)

\begin{tabular}{llllccc}
\hline Education_Level & Gender & & & N & Correlation & Sig. \\
\hline \multirow{2}{*}{ Undergraduate } & Female & Pair 1 & Actual \& Expected & 14 & .188 & .521 \\
& Male & Pair 1 & Actual \& Expected & 34 & .536 & .001 \\
\multirow{2}{*}{ Graduate } & Female & Pair 1 & Actual \& Expected & 14 & .156 & .595 \\
& Male & Pair 1 & Actual \& Expected & 44 & .535 & .000 \\
\hline
\end{tabular}

Females actual and expected marks do not correlate at either of the education levels. On the contrary, male students marks have a significant correlation (at 1\%) between expected and actual marks at both, undergrad and graduate, levels.

Table 13

Comparing gender wise score with education level (Paired Samples Test)

\begin{tabular}{|c|c|c|c|c|c|c|c|c|c|c|c|}
\hline \multirow{3}{*}{$\begin{array}{l}\text { Education } \\
\text { Level }\end{array}$} & \multirow{3}{*}{\multicolumn{2}{|c|}{ Gender }} & & \multicolumn{5}{|c|}{ Paired Differences } & \multirow[t]{3}{*}{$\mathbf{t}$} & \multirow[t]{3}{*}{ df } & \multirow{3}{*}{$\begin{array}{c}\text { Sig. } \\
\text { (2-tailed) }\end{array}$} \\
\hline & & & & \multirow[t]{2}{*}{ Mean } & \multirow[t]{2}{*}{$\begin{array}{c}\text { Std. } \\
\text { Deviation }\end{array}$} & \multirow[t]{2}{*}{$\begin{array}{c}\text { Std. } \\
\text { Error } \\
\text { Mean }\end{array}$} & \multicolumn{2}{|c|}{$\begin{array}{l}\mathbf{9 5 \%} \text { Confidence } \\
\text { Interval of the } \\
\text { Difference }\end{array}$} & & & \\
\hline & & & & & & & Lower & Upper & & & \\
\hline \multirow{2}{*}{ Undergrad } & Female & Pair 1 & $\begin{array}{l}\text { Actual - } \\
\text { Expected }\end{array}$ & -4.85714 & 12.93092 & 3.45593 & -12.3232 & 2.60895 & -1.405 & 13 & .183 \\
\hline & Male & Pair 1 & $\begin{array}{l}\text { Actual - } \\
\text { Expected }\end{array}$ & -10.5882 & 9.01889 & 1.54673 & -13.7350 & -7.4413 & -6.846 & 33 & .000 \\
\hline \multirow{2}{*}{ Graduate } & Female & Pair 1 & $\begin{array}{l}\text { Actual - } \\
\text { Expected }\end{array}$ & -6.85714 & 13.35237 & 3.56857 & -14.5665 & .85228 & -1.922 & 13 & .077 \\
\hline & Male & Pair 1 & $\begin{array}{l}\text { Actual - } \\
\text { Expected }\end{array}$ & -11.3636 & 10.20509 & 1.53847 & -14.4662 & -8.2610 & -7.386 & 43 & .000 \\
\hline
\end{tabular}

Female students' actual and expected scores at undergrad as well as at graduate level have no statistically significant difference as they observe t-statistics of 1.4 and 1.9 respectively which are lesser than 2 (benchmark) and sig value 0.183 and 0.077 - not lesser than 0.05 .

Male students' actual and expected average marks, on the other hand, are statistically different irrespective of the education level as their $t$ statistics are greater than 2 followed by sig values are lesser than 0.01 . 
Table 14

Hypothesis Assessment Summary

\begin{tabular}{llll}
$\mathrm{H}_{1} \quad \begin{array}{l}\text { there is no significant difference between the overall expected and } \\
\text { actual marks obtained. }\end{array}$ & 0.000 & Rejected \\
$\mathrm{H}_{2} \quad \begin{array}{l}\text { there is no significant difference between expected and actual marks } \\
\text { obtained by female respondents. }\end{array}$ & 0.024 & Rejected \\
$\mathrm{H}_{3} \quad \begin{array}{l}\text { there is no significant difference between expected and actual marks } \\
\text { obtained by male respondents. }\end{array}$ & 0.000 & Rejected \\
$\mathrm{H}_{4} \quad \begin{array}{l}\text { there is no significant difference between expected and actual marks } \\
\text { obtained by undergraduate respondents. }\end{array}$ & 0.000 & Rejected \\
$\mathrm{H}_{5} \quad \begin{array}{l}\text { there is no significant difference between expected and actual marks } \\
\text { obtained by graduate respondents. }\end{array}$ & 0.000 & Rejected \\
$\mathrm{H}_{6} \quad \begin{array}{l}\text { there is no significant difference between expected and actual marks } \\
\text { obtained by female undergraduate respondents. }\end{array}$ & 0.183 & Fail to Reject \\
$\mathrm{H}_{7} \quad \begin{array}{l}\text { there is no significant difference between expected and actual marks } \\
\text { obtained by male undergraduate respondents. }\end{array}$ & 0.000 & Rejected \\
$\mathrm{H}_{8} \quad \begin{array}{l}\text { there is no significant difference between expected and actual marks } \\
\text { obtained by female graduate respondents. }\end{array}$ & 0.077 & Fail to Reject \\
$\mathrm{H}_{9}$ & $\begin{array}{l}\text { there is no significant difference between expected and actual marks } \\
\text { obtained by male graduate respondents. }\end{array}$ & 0.000 & Rejected \\
\hline
\end{tabular}

\section{Discussion}

The results are aligned with other researches in this domain where it was seen that more hopeful the students were regarding their grades, the better grades they got and vice versa (Rand, 2009). Hope and optimism played a great part in achieving better grades, as these attributes help people to excel in their lives at all levels whereas optimistic attitude without hope is of little avail (Patton, Bartrum, \& Creed, 2004; Rand, 2009). Researches show that students who are ready to regulate their own study habits and achieve academic self-efficacy are more optimistic and expect better academic grades (Chemers, Hu, \& Garcia, 2001; Heikkilä \& Lonka, 2006). One reason for expecting higher grades may be that such individuals have had prior positive experience of achieving good grades as discussed by Heikkilä and Lonka (2006) and Stoecker, (1999). Whereas Rand (2009) suggests that "one possible mechanism may be through active, problem-focused coping. People with positive goal attitudes may be more likely to use active coping behaviours, even under adverse conditions" (p. 22). Thus, there may be multiple reasons for having a particular grade expectation, keeping in mind that the performance of an individual 
may rise to meet the expected grade (Rand, 2009). Self-efficacy theory by Bandura (1997) has already shown that self-efficacy plays a great role in setting higher goals. Patton, Bartrum, and Creed (2004) cite Hoover (2004), explained that in higher education students rate college achievement in terms of grade scores and selfefficacy, therefore students when given more independence as in an experiential project, their grade expectancy automatically rose.

Before drawing a conclusion from the result, it is important to note that the university admission system is based upon the academic aptitude of a student (Delaney, Harmon, \& Redmond, 2011); therefore, all students enrolled at a university have some degree of positive attitude towards the academics. Amongst these students, there are those who excel more than the others in their academic courses. These statistics show that students who score high are more ascertain regarding their marks as compared to those who do not score high grades. Rand (2009) also shows through his research that a student's performance may rise to meet the higher expectations of the grade that he/she has for a course. The reason that Rand gives for this behaviour is that people try to behave in a manner that is consistent with their expectations. Thus those expecting higher grades may work harder to obtain the grade that they are expecting from the course that they are enrolled in.

Even though there may be many reasons to expect a higher grade but problems arise when students expect a higher grade just for attending the classes or just for reading the required text (Roosevelt, 2009). Furthermore, there were students who expected to get a higher grade as they had explained to their professors that they were working hard or they think that they should get a higher grade because they have been in an academic setting since quite a time and have experienced proficiency in giving exams (Roosevelt, 2009). On the other hand, Zangenehzadeh (1988) shows that if students are interested in a course and they work hard in it, they will definitely spend more time in studying it and will expect better grades in it. But if the students feel that the course is difficult, their expectations will fall. He further highlights, that higher grade expectation is directly linked to grade inflation. He shows through his research that teachers give higher than the disserved grades in order to achieve a good teacher evaluation from students. This leads students to perceive themselves to be better in academics than they usually are. Grade inflation is a global problem and it may be playing its role in the results of the current research as well. 
Research has demonstrated that experiential projects are favoured by the students (Fenollar, Roman, \& Cuestas, 2007; Phipps, Phipps, Kask, \& Higgins, 2001; White, 2007) not only because they are more open to self-regulation but also because they are considered a way of achieving better grades. Also, the study of Cano, Lidon, Rebollar, Roman, and Saenz, (2006) must be kept in mind, according to which, as the experiential project progresses forward, the students become more confident in what they are doing regardless of the final result that they achieved. The optimistic behaviour in students may be due to the nature of assessment that they were a part of; thus, being assessed in an experiential project made them more optimistic about their grades. But these projects require continuous monitoring; thus, for those students who were unable get the expected grades, it becomes fundamental for the faculty to monitor students closely and help them learn selfregulatory skills and cognitive strategies that may assist them in acquiring a better grade (Heikkilä \& Lonka, 2006). The results of this research are in accordance with the findings of other researches where males were more optimistic about their grades than their female counterparts (Bengtsson, Persson, \& Willenhag, 2005; Beyers, 1999). Our results show that females were more realistic about their grades and earned better grades than male students in the experiential learning task. Yet, Felton, Gibson and Sanbonmatsu (2003) showed through their study that males were more optimistic about their grades and were able to achieve better grades than females in an experiential project. The reason they gave for this achievement was due to the quality of risk-taking which is naturally more present in males than in females (Beyers, 1999; Felton, Gibson, \& Sanbonmatsu, 2003). Our results did not match the results of Bengtsson, Persson, and Willenhag, (2005) who claimed that the average number of females passing a test may be more than males but males secure better grades. Our results show that females not only passed the test but that too with better grades than males.

The higher result expectancy is prominent in the graduates and undergraduate students both as per the literature review, but our results were dissimilar with the results of Heikkilä and Lonka (2006), who asserted that mature students score higher grades and their grade expectancy is much more realistic and according to their abilities. Our results show that graduate students expected higher grades than what they actually achieved and the grade expectations of undergraduate students were more realistic than the graduate students. The teachers should monitor and regulate student optimism (Heikkilä \& Lonka, 2006) which can easily be done by giving 
clear instructions and continuous feedback. Also, we should not underestimate the power of grade inflation. The students at the graduate level have been a victim of grade inflation more than the undergraduate students and thus expect higher grades than they actually deserve.

The results of this study can be compared to the study undertaken by Bengtsson, Persson and Willenhag (2005). The results are in accordance with this study as we can see a vivid difference between self-assessment of men and women but the difference occurs where they assert that this difference is more pronounced in young people than their older counterparts as our results showed vice versa. The reason for this may be found in the research of Bressler, Bressler and Bressler (2010), where they point out that the negative aspect of optimism is overrating. Sometimes students overrate their abilities and become more optimistic thus losing their connection with reality. On the other hand, Lammers, Kiesler, Curren, Cours, and Connett (2005) show that women, more than men believed that they had to work hard and start reviewing earlier for exams to accomplish a good grade. Thus working hard helped them to achieve the required grade. Nevertheless, the point discussed by Carpenter, Friar and Lipe (1994) cannot be ignored that it is the students' past experiences that help them place themselves in a certain grade range. Since females generally obtain higher grades than males, therefore, their expectation of a higher grade is more realistic.

\section{Conclusion and Recommendations}

The results of this study are aligned with the previous literature, which show that there is a significant difference between overall expected and actual marks obtained by the students. In the present experiential learning activity, it is evident from the graph that expected marks are at the higher end compared with corresponding actual marks which depict the students' behaviour of being optimistic regarding their performance. It is important to note that education level seems to be a negligible variable when it comes to grade expectation. Thus, whatever is the grade level; students always expect a higher grade. For both, undergrad and graduate level, students' expectations regarding their scores are higher than what they actually obtained. Nevertheless, statistics illustrate that the average scores of actual and expected grades for females are closer as compared with males.

It is recommended that in order to make the experiential learning fruitful through more realistic expectation, the instructor should give students feedback 
throughout the experiential project. Also, rubrics should be provided to the students before the experiential activity so that they may know where they stand and where they must go from there.

\section{References}

Bandura, A. (1997) Self-efficacy: The exercise of control. New York: W. H. Freeman.

Bell, B. S., \& Federman, J. E. (2010). Self-assessments of knowledge: Where do we go from here? Academy of Management Learning \& Education, 9(2), 342-347.

Bengtsson, C., Persson, M., \& Willenhag, P. (2005). Gender and overconfidence. Economics Letters, 86(2), 199-203.

Beyer, S. (1999). Gender differences in the accuracy of grade expectancies and evaluations. Sex Roles, 41(3-4), 279-296.

Bressler, L. A., Bressler, M. E., \& Bressler, M. S. (2010). The role and relationship of hope, optimism and goal setting in achieving academic success: A study of students enrolled in online accounting courses. Academy of Educational Leadership Journal, 14(4), 37-51.

Cano, J. L., Lidon, I., Rebollar, R., Roman, P., \& Saenz, M. J. (2006). Student groups solving real-life projects. A case study of experiential learning. International Journal of Engineering Education, 22(6), 1252-1260

Carpenter, V., Friar, S., \& Lipe, M. (1994). Evidence on the performance of accounting students: Race, gender, and expectations. Issues in Accounting Education, 8(1), $1-17$.

Centra, J. A. (2003). Will teachers receive higher student evaluations by giving higher grades and less course work? Research in Higher Education, 44(5), 495-518.

Chana, C. K. (2012). Exploring an experiential learning project through Kolb's Learning Theory using a qualitative research method. European Journal of Engineering Education, 37(4), 405-415.

Delaney, L., Harmon, C., \& Redmond, C. (2011). Parental education, grade attainment and earnings expectations among university students. IZA DP No. 5646, 1-44.

Felton, J., Gibson, B., \& Sanbonmatsu, D. M. (2003). Preference for risk in investing as a function of trait optimism and gender. The Journal of Behavioral Finance, 4(1), 33-40.

Fenollar, P., Roman, S., \& Cuestas, P. J. (2007). University students' academic performance: An integrative conceptual framework and empirical analysis. British Journal of Educational Psychology, 77, 873-891. 
Guillaumea, D. W., \& Khachikianb, C. S. (2011). The effect of time-on-task on student grades and grade expectations. Assessment \& Evaluation in Higher Education, $36(3), 251-261$.

Heikkilä, A., \& Lonka, K. (2006). Studying in higher education: Students' approaches to learning, self-regulation, and cognitive strategies. Studies in Higher Education 31(1), 99-117.

Jama, I., \& Pitts, V. R. (2005). High expectations: A "How" of achieving equitable mathematics classrooms. Negro Educational Review, 56(2), 127-134.

Javed, S., Hussain, N., \& Karim, T. S. (2014). A shift from teacher centered to experiential teaching method: A Case Study. Pakistan Business Review, 16(1), 1-33.

Jeyaraj, J. S. (2019). Traditional learning vs. experiential learning. American College Journal of English Language and Literature (ACJELL), 9, 43-46.

Kamath, S. (2014). Experiential learning vs. traditional learning methodologies. Retrieved from https:/www.knolskape.com/experiential-learning-vs-traditional-learningmethodologies/

Khachikiana, C. S., Guillaumea, D. W., \& Phama, T. K. (2011). Changes in student effort and grade expectation in the course of a term. European Journal of Engineering Education, 36(6), 595-605.

Lammers, H. B., Kiesler, T., Curren, M. T., Cours, D., \& Connett, B. (2005). How hard do I have to work? Student and faculty expectations regarding university work. Journal of Education for Business, 80(4), 210-213.

Larseingue, M., Sawyer, C. R., \& Finn, A. N. (2012). Components of students' grade expectation for public speaking assignment. Communication Education, 61(4), 428-447.

Patton, W., Bartrum, D. A., \& Creed, P. A. (2004). Gender differences for optimism, selfesteem, expectations and goals in predicting career planning and exploration in adolescents. International Journal for Educational and Vocational Guidance, 4(23), 193-209.

Pew, S. (2007). Andragogy and pedagogy as foundational theory for student motivation in higher education. Insight: A Collection of Faculty Scholarship, 2(1), 14-25.

Phipps, M., Phipps, C., Kask, S., \& Higgins, S. (2001). University students' perceptions of cooperative learning: Implications for administrators and instructors. The Journal of Experiential Education, 24(1), 14-21.

Rand, K. L. (2009). Hope and optimism: Latent structures and influences on grade expectancy and academic performance. Journal of Personality, 77(1), 231-260. 
Roosevelt, M. (2009). Student expectations seen as causing grade disputes. New York Times, L2.

Sitzmann, T., Ely, K., Brown, K. G., \& Bauer, K. N. ( 2010). Self-assessment of knowledge: A cognitive learning or effective measure? Academy of Management Learning \& Education, 9(2), 169 -191.

Stoecker, J. (1999). Optimism and grade expectancies. Psychological Reports, 83(3), 873879.

White, C. B. (2007). Smoothing out transitions: How pedagogy influences medical students' achievement of self-regulated learning goals. Advances in Health Sciences Education, 12(3), 279-297.

Zangenehzadeh, H. (1988). Grade inflation: A way out. The Journal of Economic Education, 19(3), 217-226. 